\title{
Pharmacological Potential of Benzamide Analogues and their Uses in Medicinal Chemistry
}

\section{Mohammad Asif*}

Department of Pharmacy, GRD, PGIMT, Dehradun, Uttarakhand, India

\begin{abstract}
Benzamide derivatives possess different kinds of pharmacological activities like antimicrobial, analgesic, antiinflammatory, anticancer, cardiovascular, and other biological activities. Due to these biologically significances, scientists have interesting to develop various new benzamide derivatives. There is still need to improve the already used benzamide derivatives and search for the new and more effective benzamide derivatives. This review exhibited various pharmacophoric activities of benzamides analogues which are biologically importance.
\end{abstract}

Keywords: Benzamide; Pharmaceutical applications; Biological activity

\section{Introduction}

Benzamide is a carbonic acid amide of benzoic acid. Amide is a group of organic chemicals with the general formula $\mathrm{RCO}-\mathrm{NH}_{2}$ in which a carbon atom is attached to oxygen in double bond and also attached to an hydroxyl group, where ' $R$ ' groups range from hydrogen to various linear and ring structures or a compound with a metal replacing hydrogen in ammonia such as sodium amide, $\mathrm{NaNH}_{2}-$ Amides are divided into subclasses according to the number of substituents on nitrogen. The primary amide is formed by replacement of the carboxylic hydroxyl group by the $\mathrm{NH}_{2}$, amino group. An example is acetamide (acetic acid+amide). Amide is obtained by reaction of an acid chloride, acid anhydride, or ester with an amine. Amides are named with adding '-ic acid' or '-oic acid' from the name of the parent carboxylic acid and replacing it with the suffix 'amide'. Amide can be formed from ammonia $\left(\mathrm{NH}_{3}\right)$. The secondary and tertiary amides are the compounds in which one or both hydrogens in primacy amides are replaced by other groups. The names of secondary and tertiary amides are denoted by the replaced groups with the prefix capital $N$ (meaning nitrogen) prior to the names of parent amides. Low molecular weight amides are soluble in water due to the formation of hydrogen bonds. Primary amides have higher melting and boiling points than secondary and tertiary amides.

\section{Medicine materials}

In psychiatry and related medical fields, two active substances from ihe group of Benzamides are in use Sulpiride and Amisulpiride. Another benzamide, Remoxipride was taken off the market in 1993 because of life threatening side effects.

\section{Biological Profile}

\section{Anticonvulsant activity}

A comparison of enaminones rroni various unsubstituted and p-substituted benzamides to the analogues benzyl amines has been undertaken with the aim of elucidating the essential structural parameters necessary for anticonvulsant activity [1]. Initial studies on methyl 4-N-(benzylamino)-6-methyl-2-oxocyclohex-3-en-1ate, (Scheme 1), 3-N-(benzylamino) cyclohex-2-en-1-one (Scheme 2) and 5,5-dirnethyl-3-N-(benzylamino)-cyclohex-2-en-l-one Scheme 3 indicated that benzylamines possessed significant antimaximal electrosliock seizure (MES) activity. Evaluation of the analogous benzamides revealed significant differences in their three dimensional structures. A series of $\mathrm{N}$-(tetrahydroisoqiuinolinyl)-2methoxybenzamides by high throughout screening at the novel SB204269 binding site, the structure activity relationship (SAR) studies have provided compound (Scheme 4) with high affinity and good anticonvulsant activity in animal models [2]. The anticonvulsant $\mathrm{N}-(5-$ methylisaxazol-3-yl)-2,6-dimethylbenzamide (D2916), which presents two kinds of methyl groups which could be oxidized, was submitted to various chemical oxidizing agents. Several sites and degrees of oxidization were observed. The main oxidized site was the aryl methyl group without cleavagc of the isoxazole ring, leading via carboxylic acid and primary alcohol intermediates to phthalimide and lactame derivatives. In no case was the methyl group of the isoxazole moiety hydroxylated [3]. A study on the anticonvulsant properties of 4-amino$\mathrm{N}$-(2-ethylphenyl) lbenzamide (4-AEPB) (Scheme 5), in screening mice was dosed interperitoneally (i.p.), revealed that 4 -amino- $\mathrm{N}-(2-$ ethylphenyl) benzamide (4-AEPB) was active in MES test at the dose of 10 and $100 \mathrm{mg} / \mathrm{kg}$ after $30 \mathrm{mins}$ and $4 \mathrm{~h}$, respectively against phenytoin [4,5]. A series of benzamides containing N,N-2-trimetiiyl-1,2-propane diamine as the amide moiety, the compounds were tested in the MES and pentylenetetrazole (metrazole, MET) screens for anticonvulsant activity. The 3,5-trifluoromethyl-3,5-dichloro, and 3-bromo analogues proved to be either equipotent with or mere potent than phenytoin. A short series of 4-nitro-N-phenylbenzamides (Schemes 6 and 7) was evaluated for anticonvulsant properties and neurotoxicity hi mice dosed i.p., three of the four 4-nitro- $\mathrm{N}$-phenylbenzamides were efficient in the MES test, especially $\mathrm{N}$-(2,6-dimethylphenyl)-4-nitrobenzarnide $\left(\mathrm{ED}_{50}\right.$ value in the MES test $=31.8 \mu \mathrm{M} / \mathrm{kg}, \mathrm{TD}_{50}=166.9 \mu \mathrm{mol} / \mathrm{kg}$, protective index $(\mathrm{PI}=5.2)$ and $\mathrm{N}$-(2-chloro-6-methylphenyl)-4-nitrohenzamide $\left(\mathrm{ED}_{50}\right.$ value in the MES test $=90.3 \mu \mathrm{mol} / \mathrm{kg}, \mathrm{TD}_{50}=1.068 \mu \mathrm{M} / \mathrm{kg}$, $(\mathrm{PI}=11.8)$. The latter 4-nitro-N-phenylbenzamide was also found to be active against seizures induced by scPTZ and was selected for further evaluation in rats dosed orally. In these conditions, N-(2-clhoro6-methylphenyl)-4-nitrobenzamidc was found to be, three times more active than phenytoin and 4-ainino-N-(2,6-dimethylphenyl) benzamide, two times more potent in the MES test [6].

\section{Anti-inflammatory activity}

Parsalmide (5-amino-N-butyl-2-(2-propynyloxy) benzamide) (Scheme 8), is a nonsteroidal antiinflammatory drug (NSAID),

*Corresponding author: Mohammad Asif, Department of Pharmacy, GRD, PGIMT, Dehradun, Uttarakhand, India, Tel: +91 9897088910; E-mail: aasif321@gmail.com

Received October 31, 2016; Accepted November 18, 2016; Published November 28, 2016

Citation: Asif M (2016) Pharmacological Potential of Benzamide Analogues and their Uses in Medicinal Chemistry. Mod Chem appl 4: 194. doi: 10.4172/23296798.1000194

Copyright: () 2016 Asif M. This is an open-access article distributed under the terms of the Creative Commons Attribution License, which permits unrestricted use, distribution, and reproduction in any medium, provided the original author and source are credited. 


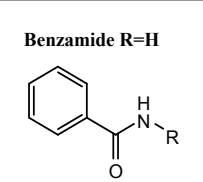

Synonyms:

Benzoic acid amide; Formula: $\mathrm{C}_{6} \mathrm{H}_{5} \mathrm{CONH}_{2}$

Phenylcarboxamide; $\quad$ Molecular weight: 121.14

Benzoylamide. Physical state: White Powder

Melting Point: $132.5-133.5$ "C

Boiling Point: 290 C

Specific Gravity: 1.08

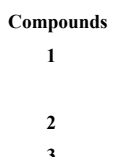

$3 \quad \mathrm{CH}$<smiles>[X]c1ccc(CNC2=CC(=O)C([R3])C([R])([R])C2)cc1</smiles>

Schemes 1-3<smiles>[R]c1cccc(OC)c1C(=O)Nc1ccc2c(c1)CCN(C)C2</smiles><smiles>CCc1ccccc1NC(=O)c1ccc(N)cc1</smiles>

Scheme 5<smiles>[R][I-]1C=CC=CC1C(=O)NC(C)(C)CN(C)C</smiles>

Scheme 6: $\mathrm{Y}=3,5-\left(\mathrm{CF}_{3}\right)_{3}, \mathrm{H}, 4-\mathrm{Cl}, 4-\mathrm{OMe}, 4-\mathrm{Me}, 3,4-\mathrm{Cl}_{2}, 3-\mathrm{Cl}, 3-\mathrm{Br}, 3,5-\mathrm{Cl}_{2}$.

commercialized in Italy until 1985 with the brand name of Synovial, that has been widely used to treat arthritic patient. In addition, it was shown to spare gastric mucosa. A series of novel substituted benzamides, related to Parsalmide, and have evaluated their activity in vitro on COX-1 and COX-2 as well as in vivo in the Carragenaninduced rat paw edema, a classical in vivo anti-inflammatory assay. Compounds (Schemes 9 and 10), which showed a favorable profile in vitro and in vivo, were screened in comparison with parsalmide for gastrointestinal (GI) tolerability in vivo in the rats. Results obtained showed that Parsalmide and compound (Scheme 10) inhibited both COX-1 and COX-2 in vitro as well as they were active in vivo. Both compounds were devoid of gastric effect at the efficacious dose. In addition, both prevented indomethacin induced gastric damage [7]. Two series of N-[4-(alkyl) cyclohexyl]-substituted benzamides, i.e., a series of $\mathrm{N}$-[4-(tert-butyl) cyclohexyl]-substituted benzamides (Scheme 11a-11h) and a series of N-[4-(ethyl) cyclohexyl]-substituted benzamides (Scheme 12a-12h) were tested for their anti-inflammatory and analgesic potencies, and gastro-intestinal irritation liability. As regards the anti-inflammatory activity, best results were shown by Scheme 11f, followed by Scheme 11d but many other compounds showed pharmacological potency. As regards the ulcerogenic action, the most potent compound was Scheme 12d, followed by Scheme 11c and 11f, but in general all compounds showed a high irritative capacity.

\section{Analgesic activity}

To explore the structure activity relationship (SAR) of a series of potent opioid agonists. Series of tropanylidene benzamides synthesized by N-ethyl-4-[(8-phenethyl-8-aza-bicyclo [3.2.1] oct-3-ylidene)pheny]-methyl]-benzamide (Scheme 13) proved extremely tolerant of structural variation while maintaining excellent opioid activity $[8,9]$. A subset was tested orally at $150 \mu \mathrm{mol} / \mathrm{kg}$ in the mouse, $48^{\circ} \mathrm{C}$ hot plate test, some compounds provided robust anti nociception and most induced Straub tail, a behavior often associated with ju opioid agonist activity. The 3 and 4-carboxy phenyl tropanylidenes provided little or no analgesic effects in the same testing paradigm most likely due to poor oral absorption or brain penetration and observed no instances of convulsions or deaths with these compounds. A series of N,N-dialkyl-4-((8-azabjcyclo[3.2.1] oct-3-ylidene)phenylmethyl] benzamides, the lead compounds bind with exceptionally high affinity to the $\delta$ opioid receptor and were also highly selective for $\delta$ verus $\mu$ opioid binding. They were full $\delta$ agonists and were antinociceptive in tlie mouse abdominal irritant test. They appear to have a lower convulsant liability than earlier $\delta$ agonists. The $\delta$ opioid agonists have been seen as potentially safer alternatives to conventional agonists as pain relieving agents. Alternative therapeutic roles for these agents, in neuropathic or inflammatory pain, depression, parkinson's disease and<smiles>[R]c1cccc([R])c1NC(=O)c1ccc([N+](=O)[O-])cc1</smiles>

Scheme 7: $\mathrm{R}_{1}=\mathrm{F}, \mathrm{CH}_{3}, \mathrm{CH}_{3}, \mathrm{C}_{2} \mathrm{H}_{5}$.<smiles>C#CCOc1ccc(N)cc1C(=O)NCCCCCCCCCCCCCCC</smiles>

Scheme 8<smiles>[R]Oc1cc(N)ccc1C(=O)NCCC</smiles>

Scheme 9 

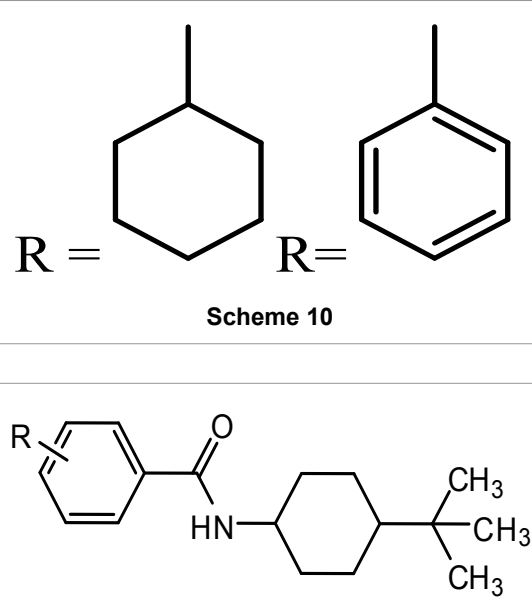

Scheme 11a-h

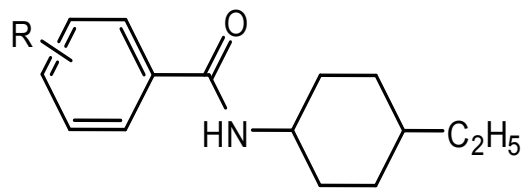

a: $\mathrm{R}=3,4,5-\left(\mathrm{CH}_{3} \mathrm{O}\right)_{3} ; \mathrm{b} ; \mathrm{R}=4-\mathrm{Cl} ; \mathrm{c}: \mathrm{R}=4-\mathrm{F}$;

d: $\mathrm{R}=4-\mathrm{Br} ; \mathrm{e}: \mathrm{R}=2,4-\mathrm{Di}-\mathrm{Cl} ; \mathrm{f}: \mathrm{R}=\mathrm{H} ; \mathrm{g}: \mathrm{R}=4-\mathrm{CH}_{3}, \mathrm{~h}: \mathrm{R}=4-\mathrm{NO}_{2}$

Scheme 12a-h<smiles>CCNC(=O)c1ccc(C(=C2CC3CCC2N(CCc2ccccc2)C3)c2ccccc2)cc1</smiles>

lung cancer have been suggested [10]. N-alkyl-4-[(8-azabicyclo[3.2.1]oct-3-ylidene) phenylmethy]]-benzamicies, the tertiary amide 6 opioid agonist (Scheme 14) was a potent antinociceptive agent. Compound (Scheme 14) was metabolized in vitro and in vivo to secondary amide, a potent and selective $\mu$ opioid agonist. The SAR of a series of N-alkyl4 -[(8-azabicyclo[3.2.1]-oct-3-ylidene) phenylmethyl] benzamides was also tested [11].

\section{Serotonin (5-HT) activity}

Serotonin (5-HT) is a neurotransmitter responsible for a wide range of pharmacological reactions. Many gastrointestinal prokinetics such as benzamides (e.g., metoclopramide, cisapride) have binding affinity tor $5-\mathrm{HT}_{4}$ receptors and the pharmacological effect of these compounds is thought to be based on $5-\mathrm{HT}_{4}$ receptor agonism. A set of benzamide derivatives were tested as selective $5-\mathrm{HT}_{4}$ receptor agonists. They performed modification of the parent compound 4-amino-5chloro-2-melhoxy-N-[1-(6-oxo-6-phenylhexylpiperidin-4-yl methyl) benzamide (Scheme 15) which have tlie ability to enhance both upper and lower gastrointestinal motility without any significant adverse effects [12]. A Series of 4-amino-5-chloro-2-methoxy-N-(piperidin-4yl-methyl) benzamides with a polar substituent group at the 1-position of the piperidine ring was evaluated for its effect on gastrointestinal motility. The benzoyl, phenylsulfonyl, and benzylsulfonyl derivatives accelerated gastric emptying and increased the frequency of defecation. One of them, 4-amino-N-[1-[3-benzyl sulfonyl)propyl]piperidin-4-yl methyl]-5-chloro-2-methoxy benzamide (Scheme 16), was a selective 5-HT4 receptor agonist offering potential as a novel prokinetic with reduced side effects derived from $5-\mathrm{HT}_{3}$ and dopamine $\mathrm{D}_{7}$ receptor binding affinity. In the oral route of administration, this compound enhanced gastric emptying and defecation in mice, and has a possibility as a prokinetic agent, which is effective on both the upper and lower gastrointestinal tract [13]. (Azaadamantanone was converted to a series of amino azacadamantane benzamides (Scheme 17a-d) were profiled for serotonin receptor activity. Aminomethyl azadaniantaiie<smiles>[X]c1cccc(C(=C2CC3CCC(C2)N3[R])c2ccc(C(=O)N([R])[R])cc2)c1</smiles>

Scheme 14: $\mathrm{R}_{1}=2$-Phenethyl; $\mathrm{R}_{2}, \mathrm{R}_{3}=\mathrm{C}_{2} \mathrm{H}_{5} ; X=\mathrm{H}$.<smiles>COc1cc(N)c(Cl)cc1C(=O)NCC1CCN(CCCCC(=O)c2ccccc2)CC1</smiles>

Scheme 15<smiles>COc1cc(C(=O)NCC2CCN(CCCS(=O)(=O)Cc3ccccc3)CC2)cc(Cl)c1N</smiles>

Scheme 16<smiles>COc1cc(N)c(Cl)cc1C(=O)NCC1C2CC3CC1CN(C3)C2</smiles> 
SC-54750 is a potent 5-HT4 agonist and antagonist with in vivo efficacy in gastroparesis models and also inhibits cisplatin induced emesis [14]. Several fused bicycle systems have been investigated to serve as the core structure of potent and selective 5-HTIF receptor agonists. Replacement of the indole nucleus in Scheme 18 with indazole and inverted Indazole provided more potent and selective 5-HTIF receptor ligands (Scheme 19). Indoline and 1,2-benzisoxazole systems also provided potent 5-HTIF receptor agonists. The 5-HT1A receptor selectivity of the indoline and 1,2-benzisoxazole-based $5 \mathrm{HT} 1 \mathrm{~F}$ receptor agonists could be improved with modification of the benzoyl moiety of the benzamides. The combination of $\mathrm{D} 4$ and $\mathrm{S}-\mathrm{HT}_{2} \mathrm{~A}$ receptor blockade is attractive for a number of reasons. A favorable $5-\mathrm{HT}_{2} / \mathrm{D}_{2}$ ratio may limit the propensity of a compound to induce extrapyramidal symptoms (EPS) (Scheme 20a-o). 5-HT2A antagonists are also known to be efficacious in the treatment of negative symptoms of schizophrenia. In addition, cortical dopaminergic systems are regulated by 5-HT indirectly via glutaniatergic and GABAnergic systems, suggesting a synergistic relationship between the dopaminergic and serotonergic systems. A series of $\mathrm{N}$-[(3S)-1-benzylpyrrolidin-3-yl]- (2-thienyl) benzamides (Scheme 21) has been found to bind with high affinity to the human $\mathrm{D}_{4}\left(\mathrm{HD}_{4}\right)$ and $5-\mathrm{HT}_{2} \mathrm{~A}$ receptors. Several compounds displayed selectivity for these receptors versus $\mathrm{HD}_{2}$ and $\alpha_{1}$ adrenergic receptors of over 500-fold [15,16]. A series of N- [I-(1-substituted 4-piperidinyl] benzamides were prepared and compounds were tested for their binding to 5-HT4 receptors and effects on gastrointestinal motility in conscious dogs. 4-Amino-N-[1-(4-aminobutyl)-4-piperidinylniethyl]4-pipericlinyl]-5-chloro-2-methoxy-benzamide (Scheme 21) was found to have a potent binding affinity for $5-\mathrm{HT}_{4}$ receptor $\left(\mathrm{IC}_{50}\right.$ : $6.47 \mathrm{mM}$ ) and showed excellent prokinetic activity [17]. The KDR-5169, 4-amino-5-chloro-N-[1-(3-fluoro-4-methoxybenzyl) piperidin-4-yl]2-(2-hydroxy ethoxy) benzamide hydrochloride dehydrate (Scheme 22) is a prokinetic with a dual action i.e., stimulation of the 5-HT4 receptor and antagonism of the dopamine $\mathrm{D}_{2}$ receptor. The in vitro activities of KDR-5169 towards both receptors and demonstrated the effect of the compound on gastrointestinal motor activity in conscious dogs and rats.<smiles>COc1cc(N)c(Cl)cc1C(=O)NNCC1C2CC3CC1CN(C3)C2</smiles><smiles>CNS(=O)(=O)Cc1ccc2[nH]cc(CCN(C)C)c2c1</smiles>

Scheme 18

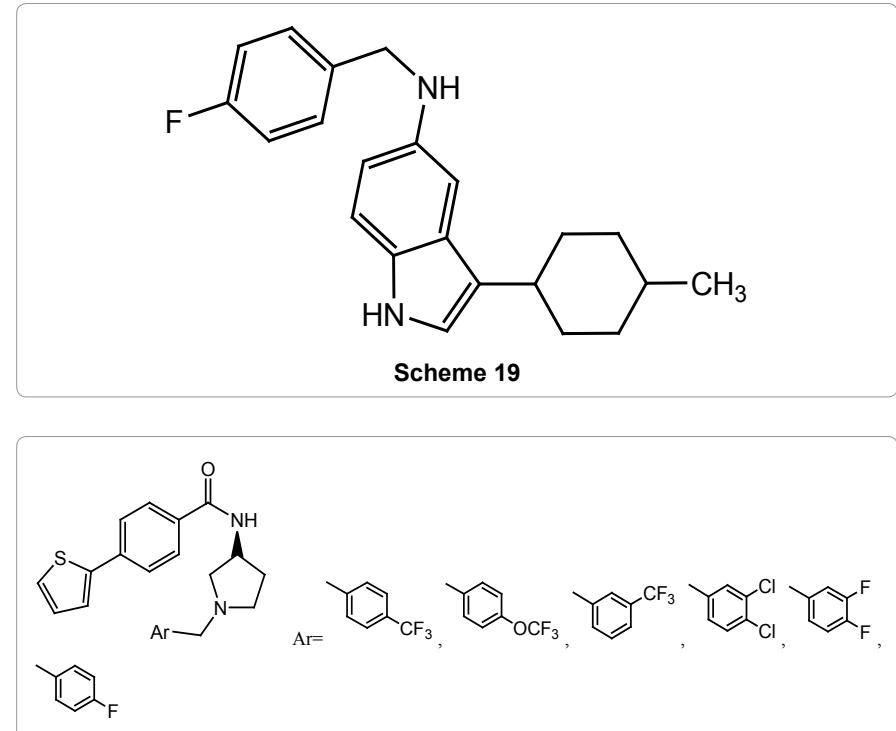

Scheme 20a-o<smiles>COc1ccc(C(=O)NCCN2CCN(c3ccc(Cl)cc3)CC2)cc1</smiles>

Scheme 21<smiles>COc1ccc(CN2CCC(NC(=O)c3cc(Cl)c(N)cc3OCCO)CC2)cc1F</smiles>

Antitumor activity

A novel class of $\mathrm{N}$-(4-\{[4-(lH-benzoimidazol-2-yl) aryl amino $]$ methyl $\}$-phenyl) benzamides and described them as inhibitors of the endo- $\beta$-glucuronidase that degrades hepranase. Heparanase, an endo$\beta$-D-glucuronidase that degrades heparin sulfate glycosaminoglycans in the extra cellular matrix (ECM) and the basement membrane, is involved in tumor cell invasion, angiogenesis, and other physioiogical and pathological processes $[18,19]$. Among the compounds N-(4$\{[4-(1 \mathrm{H}$-benzoirnidazol-2-yl)phenylamino $]$-methyl $\}$-phenyl)-3bromo-4-methoxybenzamide (Scheme 23), and $\mathrm{N}$ - $(4-\{[5-(1 \mathrm{H}-$ benzoimidazol-2-yl)-pyridin-2-yl-amino]methyl\}-phenyl)-3-bromo4-methoxybenzamide (Scheme 24) displayed good heparanase inhibitory activity $\left(\mathrm{IC}_{50} 0.23-0.29 \mu \mathrm{M}\right)$, with the latter showing oral exposure in mice. Iodobenzamides are reported to possess sonic affinity for melanoma. In order to identity the compound having the most appropriate pharmacokinetic properties as a potential melanoma imaging agent, thirteen new $\left[{ }^{125} \mathrm{I}\right]$ radioiodobenzamides with a butylenes 
<smiles>CCNc1ccc(NC(C)=O)cc1</smiles>

Scheme 23

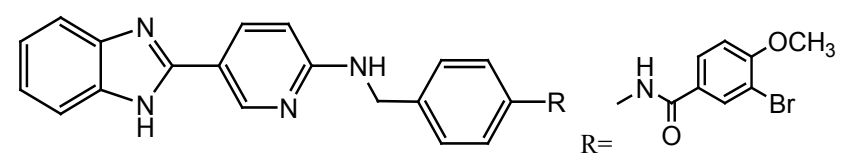

Scheme 24

amide-amine spacer and various substituents on the terminal amino group were investigated. The radioiodination and biodistribution in $\mathrm{B}_{16}$ melanoma bearing (57BL6 mice are described and compared to [125I] labeled N-(2-diethylaminoclhyl)-4-iodoben/amide $\left\{\left[{ }^{125} \mathrm{I}\right] \mathrm{BZA}\right)$ (Scheme 25), with reference compound changes in the terminal amino constituents induced modifications of lipophilicity, tumor uptake and organ distribution. The dimethyl aminobutyl iodobenzamide appeared to be the most promising radiopharmaceutical imaging agent for the detection of melanoma and its metastases [20]. In the course of investigations aimed at improving the biological characteristic of iodobenzamides for melanoma therapeutic applications, four derivatives containing a spermidine chain have been prepared and radiolabeled with In vitro studies showed that all compounds displayed high affinity for melanin superior to the reference compound BZA. In vivo biodistribution was investigated in $\mathrm{B}_{16}$ melanoma-bearing mice. All four compounds, particularly benzamide, showed accumulation in the tumor, but lower, however than that of BZA. Moreover, high concentrations of radioactivity in the organs, namely, the liver and lungs, demonstrated nonspecific tumoral uptake, hi view of these results, compounds (Schemes 26-29) do not appear to be suitable radiopharmaceuticals for melanoma radionuclide therapy [21].

\section{Antimicrobial activity}

Some 5-(2-suhstituled-1,3-thiazol-5-yl)-2-hydroxybcnzamides (Scheme 30), 5-\{2-[(N-substiluted aryl)amino]-1,3-thiazol-5-yl)-2hydroxybenzamides (Scheme 31) and their 2-butoxy and 2-propyJoxy derivatives (Scheme 32) and their anti-fungal activity. Among the tested compounds, the compound 5-[2-(A/--3-ehlorophcnyl)1,3-thiazol-5-yl]-2-butyioxybenzamide emerged as most active compound [22]. The synthesis of some N-(2-hydroxy-4-substituted phenyl) benzamides, phenyl acetamides and furamidcs as the possible metabolites of benzoxazoles was performed in order to determine their in vitro antimicrobial activity against three gram positive bacteria, two gram negative bacteria and the fungus $C$. albicans and their activities were compared with several control drugs. Some compounds were found active at a MIC value of $12.5 \mu \mathrm{g} / \mathrm{ml}$ against the gram-negative microorganism $P$. aeroginosa. Most of the compounds showed antibacterial activity at a MIC value $25 \mu \mathrm{g} / \mathrm{ml}$ against the gram-positive bacteria S. aureus. For the antifungal activity against $C$. albicans, one of the compound was found to be more active than the other derivatives. One compound possessed two dilutions better antifungal activity than its cyclic analogue, benzoxazole IV, against C. albicans [23]. The N-(l-Phenyl-4-carbetoxypyrazol-5-yl)-, N-(indazol-3-yl)-and A/-(indazol-5-yl)-2-iodobcnzamides (Scheme 33), with benodanillike structure, which were synthesized by refluxing in acetic acid the corresponding benzotriazinones with potassium iodide for $1 \mathrm{~h}$ in order to study the role on the antifungal activity of the $\mathrm{N}$-substitution with an aromatic heterocyclic system on benzamide moiety. Among the tested iododerivatives, some of the compounds possessed interesting activities toward some phytopathogenic fungal strains [24]. Some N-(ohydroxypheny! benzamides and benzacetamides to determine their in vitro antimicrobial activity against two gram positive bacteria, three gram negative bacteria and the fungus C. albicans. The compounds were compared with several control drugs. The derivative (Scheme 34), 4-amino-N-(o-hydroxyphenyr) benzamide, was found active at an MIC value of $25 \mu \mathrm{g} / \mathrm{ml}$ against the gram negative microorganism $K$. pneumoniae. Most of the compounds exhibited antibacterial activity<smiles>[R]N([R])CCCCNC(=O)c1ccc(I)cc1</smiles>

Scheme 25: $\mathrm{R}_{1}=\mathrm{H}, \mathrm{CH}_{3}, \mathrm{C}_{2} \mathrm{H}_{5}, \mathrm{n}-\mathrm{C}_{2} \mathrm{H}_{5}, \mathrm{n}-\mathrm{C}_{3} \mathrm{H}_{7}, \mathrm{n}-\mathrm{C}_{4} \mathrm{H}_{9}$; $\mathrm{R}_{2}=\mathrm{H}, \mathrm{CH}_{3}, \mathrm{C}_{2} \mathrm{H}_{5}, \mathrm{n}-\mathrm{C}_{2} \mathrm{H}_{5}, \mathrm{n}-\mathrm{C}_{3} \mathrm{H}_{7}, \mathrm{n}-\mathrm{C}_{4} \mathrm{H}_{9}$.<smiles>[R20]CCCN([R1])CCCCNC(=O)c1ccc(I)cc1</smiles>

Scheme 26-29: $\mathrm{R}_{1}=\mathrm{R}_{2}==\mathrm{C}_{2} \mathrm{H}_{5} ; \mathrm{H} ;=\mathrm{C}_{3} \mathrm{H}_{7}, \mathrm{H}$; $=\mathrm{C}_{3} \mathrm{H}_{7}, \mathrm{CH}_{2} \mathrm{Ph} ;=\mathrm{C}_{3} \mathrm{H}_{7} \mathrm{CH}_{3}$.

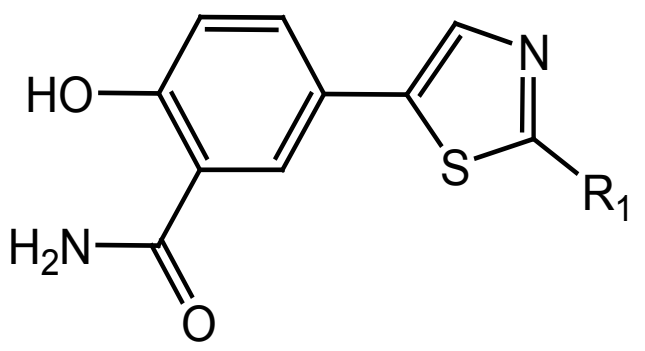

Scheme 30: $\mathrm{R}_{1}=\mathrm{H}, \mathrm{NH}_{2}, \mathrm{CH}_{2} \mathrm{CH}\left(\mathrm{CH}_{3}\right)_{2}$

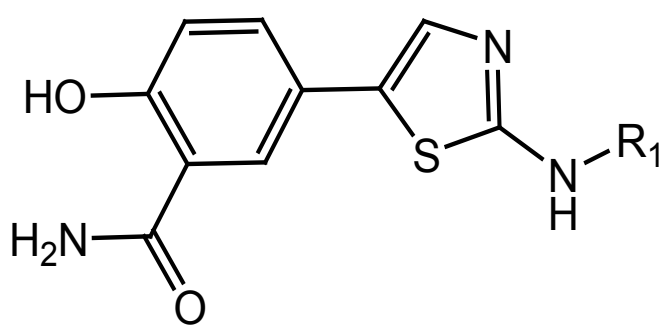

Scheme 31: $\mathrm{R}_{1}=\mathrm{C}_{6} \mathrm{H}_{5} 2-\mathrm{CH}_{3} \mathrm{C}_{6} \mathrm{H}_{5}$ 4- $\mathrm{CH}_{3}-\mathrm{C}_{6} \mathrm{H}_{5}, 4-\mathrm{Br}-\mathrm{C}_{6} \mathrm{H}_{5}$ 3- $\mathrm{Cl}-\mathrm{C}_{6} \mathrm{H}_{5}, 4-\mathrm{Cl}-\mathrm{C}_{6} \mathrm{H}_{5}$

2- $\mathrm{CF}_{3}-\mathrm{C}_{6} \mathrm{H}_{5}, 3-\mathrm{Cl}, 4-\mathrm{CH}_{3}-\mathrm{C}_{6} \mathrm{H}_{5}$ $2-\mathrm{C}_{5} \mathrm{H}_{5} \mathrm{~N}, 6-\mathrm{CH}_{3}-2-\mathrm{C}_{5} \mathrm{H}_{5} \mathrm{~N}$. 


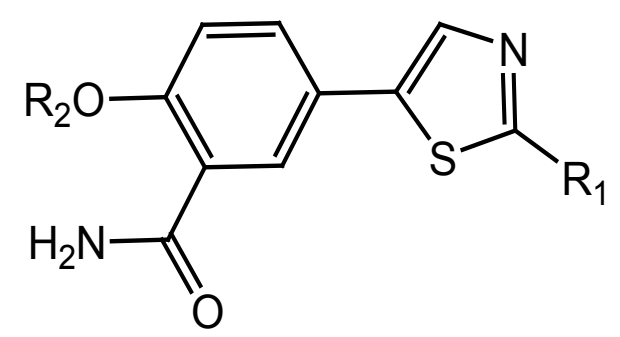

Scheme 32: $\mathrm{R}_{1}=-\mathrm{CH}_{3}-\mathrm{NH}_{2} \mathrm{HC}_{6} \mathrm{H}_{5} \mathrm{NH}-4-\mathrm{CH}_{3}-\mathrm{C}_{6} \mathrm{H}_{5}, \mathrm{CH}_{3}$, $\mathrm{NHC}_{6} \mathrm{H}_{5}, \mathrm{NH}-3-\mathrm{Cl}-\mathrm{C}_{6} \mathrm{H}_{5}$ $\mathrm{R}_{2}=$ Propyl, Butyl.<smiles>NC(=O)c1ccc(Cl)cc1I</smiles>

Scheme 33<smiles>[R]c1ccc(O)c(NC(=O)[X]c2c([R])c([R4])c([R])c([R])c2[R])c1</smiles>

Scheme 34: $X=\mathrm{CH}_{3}, \mathrm{R}_{2}=\mathrm{H}, \mathrm{Cl}, \mathrm{CH}_{3}, \mathrm{NO}_{2} \mathrm{R}_{1}=\mathrm{H}, \mathrm{CH}_{3}, \mathrm{OCH}_{3}, \mathrm{R}_{2}=\mathrm{H}, \mathrm{OCH}_{3}, \mathrm{R}_{3}=\mathrm{H}$, $\mathrm{Cl}, \mathrm{Br}, \mathrm{CH}_{3}, \mathrm{NO}_{2}, \mathrm{OCH}_{3}, \mathrm{C}\left(\mathrm{CH}_{3}\right)_{3}, \mathrm{~F} ; \mathrm{R}_{4}=\mathrm{H}, \mathrm{OCH}_{3}, \mathrm{R}_{5}=\mathrm{H}, \mathrm{OCH}_{3}$.

at MIC value of $25 \mu \mathrm{g} / \mathrm{ml}$ against $P$. aureginosa. For the antifungal activity against C. albicans, compounds (Scheme 34) were found more active than the other derivatives (MIC $12.5 \mu \mathrm{g} / \mathrm{ml}$ ). The antimicrobial activity of some of these benzamides and phenyl acetamide derivatives (Scheme 34), possible metabolites of benzoxazoles, was also compared with that of the cyclic analogues. Compound (Scheme 34) possessed two dilutions better antibacterial activity than its cyclic analogue the benzoxazole derivative against $C$. albicans, whereas it was possessing one dilution better antibacterial activity against $S$. faecalis and $K$. pneumoniae.

\section{Antidepressant activity}

Although a wide assortment of agents is currently available for the treatment of depression, this disorder remains poorly managed in a large proportion of patients. The effects of selective antagonists of the tachykinin $\mathrm{NK}_{1}, \mathrm{NK}_{2}$ and $\mathrm{NK}_{3}$ receptors in the forced swim test, a commonly used scrcen for antidepressants. Rats were given CP-96, 345 (2S,3S)-cis-2-(diphenylmethyl)-N-[(2-methoxyphenyl)methyl]-1-azabicyclo[2.2.2] octan-3-amine, SR 48968 (S)-N-methyl$\mathrm{N}$-[4-(4-acetylamino-4-phenylpiperidino)-2-(3,4-dicl)lorophenyl)- butyl) benzamide, or SR 142801 (S)-(N)-(1(3-(l-benzoyl-3-(3,4dichlorophenyl) piperidin-3-yl) propyl-4-phenylpiperidin-4-yl)-Nmethylacetamide antagonists of the $\mathrm{NK}_{1}, \mathrm{NK}_{2}$ and $\mathrm{NK}_{3}$ receptors, respectively at doses of $2.5,5$ and $10 \mathrm{mg} / \mathrm{kg}$ i.p., The time of immobility during the forced swim test was used as an indicator of antidepressant activity of the antagonists. All antagonists had decreased immobility times.

\section{Miscellaneous}

$\mathrm{K}_{\text {ATP }}$ channels are found in different tissues, such as the heart vascular smooth muscle, central neurons and pancreatic $\beta$ cells. Activators of $K_{\text {ATP }}$ channels of smooth muscle (e.g., diazoxide and pinacidil) have been explored as drugs for treatment of cardiovascular diseases. It has been suggested that activators of $\beta$ cell $\mathrm{K}_{\mathrm{ATP}}$ channels can be used in the treatment of metabolic diseases through an inhibition of insulin release to induce $\beta$ cell rest. The 2-(4-methoxyphenoxy)-5nitro-N-(4-sulfamoylphenyl) benzamides (Schemes 35-43), its close analogues as an activator of Kir6.2/SUR/K $\mathrm{K}_{\mathrm{ATP}}$ channels of $\beta$ cells and inhibit glucose stimulated insulin release [25-27].

The NOP $\left(\mathrm{ORL}_{1}, \mathrm{OP}_{4}\right)$ receptor is a $\mathrm{G}$ protein-coupled receptor closely related to the $\mathrm{OP}_{1}, \mathrm{OP}_{2}$ and $\mathrm{OP}_{3}$ opioid receptors but having poor affinity with the opioid peptides. The NOP receptor is widely distributed in both central and peripheral nervous system and it is involved in many physiological effects including nociception, attenuation of anxiety, inhibition of learning and memory, stimulation of food intake, diuresis inhibition of reward pathways in drug addiction, inhibition of tachykinergic bronchoconstriction, hypotension, bradycardia, and inhibition of colonic motility. A series of 4-amino-2-methylquinoline and 4-aminoquinazoline derivatives (Scheme 44a-n), including the reference NOP antagonist JTC-801 and their in vitro pharmacological properties were investigated. 3-Substitution of the quinoline ring resulted very critical for affinity, so 3-methyl derivative (Scheme 44c) showed a similar potency compared with reference (Scheme 44a) while bulky lipophilic or electron withdrawing groups in the same position<smiles>[R3]CC([R])([R])c1ccccc1N([R4])C(=O)c1cc([R2])ccc1[X]</smiles>

Scheme 35-43: $\mathrm{R}_{1}=\mathrm{OCH}_{3}, \mathrm{H} \mathrm{R}_{2}=\mathrm{NO}_{2}, \mathrm{H}, \mathrm{NH}_{2}, \mathrm{CN} \mathrm{R}=4-\mathrm{SO}_{2} \mathrm{NH}_{2}, 4-\mathrm{OCH}_{3}$, $4-\mathrm{F}, 4-\mathrm{COCH}_{3}, 3-\mathrm{SO}_{2} \mathrm{NH}_{2}, 2-\mathrm{SO}_{2}, \mathrm{NH}_{2}, 4-\mathrm{Cl} \mathrm{R}_{4}=\mathrm{H}^{2}, \mathrm{CH}_{3}, \mathrm{CH}_{2} \mathrm{CH}_{3}$.<smiles>[R][X]c1nc2ccc(NC(=O)c3ccccc3COc3ccc([R])cc3)cc2c(N)[R]1[R]</smiles>

Scheme 44: (a-n) $\mathrm{R}_{1}=\mathrm{CH}_{3},\left(\mathrm{CH}_{2}\right)_{4}, \mathrm{H} ; \mathrm{R}_{2}=\mathrm{H}, \mathrm{C}_{2} \mathrm{H}_{5},\left(\mathrm{CH}_{2}\right)_{4}, \mathrm{C}_{6} \mathrm{H}_{5}, \mathrm{CO}_{2} \mathrm{C}_{2} \mathrm{H}_{5}$; $\mathrm{R}_{3}=\mathrm{C}_{2} \mathrm{H}_{5} ; \mathrm{X}=\mathrm{C}, \mathrm{N}$. 
strongly decreased affinity [28]. The epidermal growth factor receptor (EGFR) protein tyrosine kinase (PTK) is one of the important kinases that play a fundamental role in signal transduction pathways. EGFR and its ligands (EOF, TGF-a) have been implicated in numerous tumors of epithelial origin and proliferative disorders of the epidermis such as psoriasis. Therefore, the design of inhibitors toward EGFR-PTK is an attractive approach foe the development of new therapeutic agents. The benzamides (Scheme 45) and the benzamidines (Scheme 46) as well as the cyclic benzamidines (Scheme 47) were designed as the mimics of 4 -anilino quinazolines for an inhibitor of EGFR tyrosine kinase. The specific inhibitions of $\mathrm{v}$-Src kinase were observed in the benzamides, and the benzamidine, whereas the specific inhibitions of v-Src kinase were observed in the benzamide and benzamidine at a $10 \mu \mathrm{g} / 1 \mathrm{ml}$ [29]. The continued quest for an orally active MCHrl antagonist as an effective treatment for obesity, a series of potent benzamide containing $\mathrm{MCHrl}$ antagonists has been identified. The compound with the best combination of MCHrl binding affinity and functional activity had good oral bioavailability in dog and was evaluated in a DIO mouse model for efficacy. Compound (Scheme 48) demonstrated sustained moderate efficacy when dosed at $30 \mathrm{mpk}$ qd in this chronic model of weight loss [30]. Several potent MCHrl antagonists based on ortho-<smiles>CCc1ccc(OCc2ccccc2C(=O)Nc2ccc3nc(C)cc(N)c3c2)cc1</smiles>

(JTC-801)<smiles>[R]NC(=O)c1cc(OC)c(OC)cc1N</smiles>

Scheme 45<smiles>[R]NC(=N)c1cc(OC)c(OC)cc1N</smiles>

Scheme 46

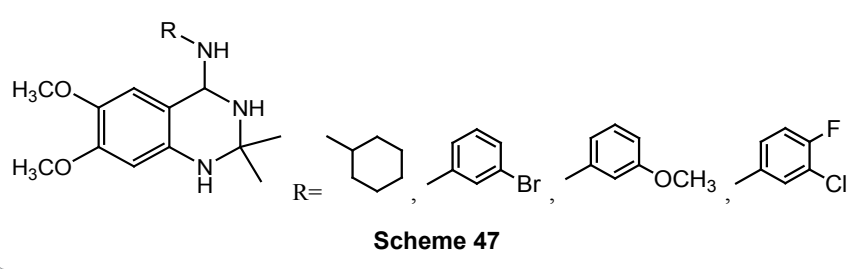<smiles>[R]C(=O)NC1CCN(Cc2ccc3c(c2)OCO3)CC1</smiles>

amino benzamide and nicotinamide scaffolds exemplified by Schemes 49 and 50 have been designed and evaluated for the treatment of obesity. Compounds from both these series exhibit dose-dependent sustained efficacy in an obese murine weight loss model [31]. The identified (bis) sulfonic acid, (bis) benzamidcs (Schemes 51-54) as compounds that interact with the follicle stimulating hormone receptor (FSHR) and inhibit FSH-stimulated cAMP accumulation with $\mathrm{IC}_{50}$ values in the low micromolar range. The SAR studies using novel-analogues of Schemes 51-54 revealed that two phenylsulfonic acid moieties were necessary for activity and that the $\mathrm{C}-\mathrm{C}$ double bond of the stilbene sub-series was the optimum spacer connecting these groups [32]. Selected analogues (Schemes 52-54) were also able to block FSHRdependent estradiol production in rat primary ovarian granulose cells and progesterone secretion in a clonal mouse adrenal $\mathrm{Y}_{1}$ cell line. $\mathrm{IC}_{50}$ values of these compounds in these assays were in the low microniolar range. Optimization of the benzoic acid side chains of (Schemes 5154) led to gains in selectivity versus activity at the thyroid stimulating hormone (TSH) and receptor (TSHR). Two benzamide derivatives as dopamine D4 receptor antagonists, YM-50001 (4) and N-[2-[4(chlorophenyl]piperizin-l-yl]ethyl]-3-methoxybenzamide (Schemes 55 and 56), were labeled by positron-emitter and their pharmacological specificities to dopamine D4 receptors were examined by quantitative autoradiography and position emission tomography (PET) [33]. Various neurokinin receptor antagonists especially dual $\mathrm{NK}_{1} / \mathrm{NK}_{2}$ antagonists, may represent a treatment option for asthma and other airway diseases, particularly since lung tissue from asthma patients has been shown to over express $\mathrm{NK}_{1}$ and $\mathrm{NK}_{2}$ receptors. The $\mathrm{N}-\left[\left(\mathrm{R}_{1} \mathrm{R}\right)-(\mathrm{E})\right.$ 1-(4-Chlorobenzyl)-3-(2-oxoazepan-3-yl)carbomyl]alIyl-N-methyl3,5-bis(trifuoromethyl)benzamide (Schemes 57) DNK 333) exhibiting a 5-fold improved affinity to the $\mathrm{NK}_{2}$ receptor in comparison to Scheme 58. Simplification of the structure via elimination of a chiral centre led to 3 -[N-3,5-bis(trifuoroniethyl)benzoyl-N-(3,4-dichlorobenzyl)-Nmethylhydrazino]-iV-[R-2-oxo-azepan-3-yl] propionamide a potent and fairly balanced $\mathrm{NK}_{1} / \mathrm{NK}_{2}$ antagonist. The ( \pm )-N-[5-(Diethylaniino)l-phenylpentyl]-4-nitrobenzamide hydrochloride (Scheme 59) is known as the representative of new class III antiarrhythmic drugs which are highly effective and well tolerated in patients with atrial flutter and fibrillation or supraventricular tachycardia. A series of 1,5-diaminopentane derivatives, structurally related to nibetan, was tested for antifibrillatory activity. Some of the compounds were found to be more potent than nibentan and possessed a longer duration of action. The antifibrillatory activity of $( \pm)-\mathrm{N}$-[5-(diethylamino)-1(4-methoxyphenyl) pentyl]-4-nitrobenzamide hydrochloride was comparable to that of nibentan but exceeded the potency of D-satalol and sematilide $[34,35]$.

\section{Discussion}

Several biological activities studied by different researchers in organic scaffolds are based on the benzamide systems. The effects of substitutions on benzamide either by aliphatic, aromatic or heteroaromatic systems are leading to various types of biological activities. Few benzamide congeners were screened out as the most effective molecules delivering immense activity in each of the target 
<smiles>[R]CN1CCC(NC(=O)c2cc([R])ccc2[R])CC1</smiles>

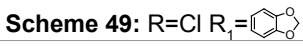<smiles>[R]CN1CCC(NC(=O)c2cc([R])ccc2[R])CC1</smiles>

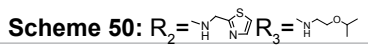

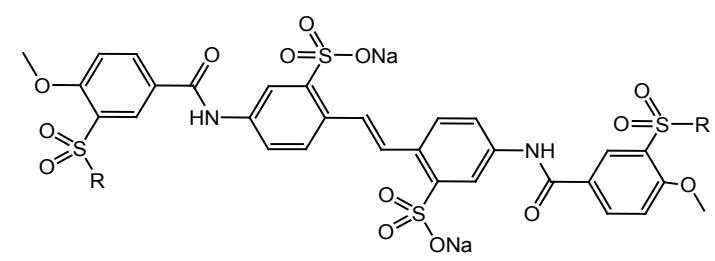<smiles>CN1CCS(=O)(=O)CC1</smiles><smiles>CS(=O)(=O)c1ccc(C(=O)Nc2ccc(/C=C/c3ccc(NC(=O)c4ccc(S(C)(=O)=O)cc4)cc3S(=O)(=O)O)c(S(=O)(=O)O)c2)cc1</smiles>

Scheme 52

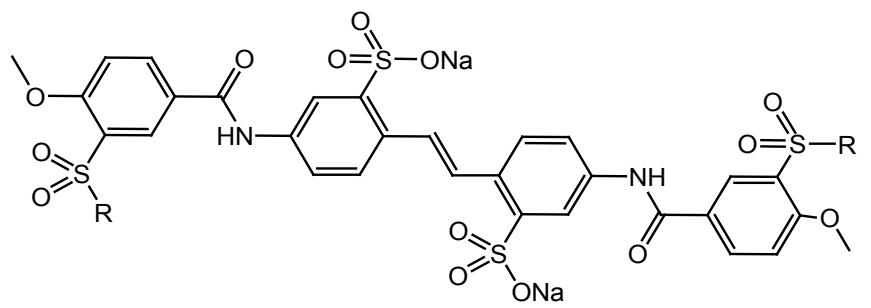

Scheme 53

studies. Upon varying or substituting electron-withdrawing or electronreleasing functional groups directly to the nitrogen atom of benzamide or on the phenyl/benzyl ring attached to the benzamide, the respective biological action was found to vary in almost all cases. After careful study of numerous examples in terms of targeted molecular designs, one may have the idea to structure further classes of featured molecules, leading to an innovative drug discovery. The various substitutions were chosen in order to identify the possible structure-activity relationships. Various compounds synthesized in this way are subjected to screen for their biological activity. The benzamide template contains some building features and pharmacological points that provides a wide range of different biological targets in medicinal chemistry. Benzamide analogues have been a great interest of biological activities that can be found across number of different therapeutic areas.

\section{Conclusion}

In conclusion, benzamide derivatives were synthesized by different methods and evaluated as different types of biologically active agents. The Substituted benzamides will be consider as bioactive compounds and may be treated as medicinal material. It can be concluded that this class of compounds certainly holds great promise towards good active leads in medicinal chemistry. A further study to acquire more information concerning pharmacological activity is in progress.

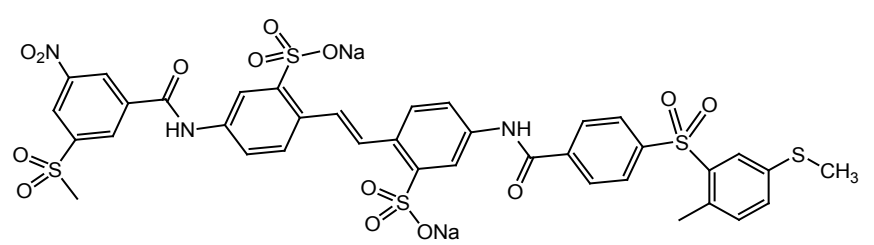

Scheme 54<smiles>COc1ccc(CN2CCC(NC(=O)c3cc(Cl)c(NC(=O)C4CC4)cc3OC)C2)cc1</smiles>

Scheme 55

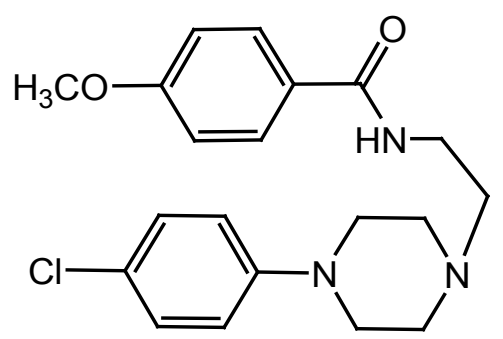

Scheme 56<smiles>CC(C(=O)c1cc(C(F)(F)F)cc(C(F)(F)F)c1)C(/C=C/C(=O)N[C@H]1CCCCNC1=O)Cc1ccc(Cl)c(Cl)c1</smiles>

Scheme 57 
Citation: Asif M (2016) Pharmacological Potential of Benzamide Analogues and their Uses in Medicinal Chemistry. Mod Chem appl 4: 194. doi: 10.4172/2329-6798.1000194

Page 9 of 10<smiles>CC(C(=O)c1cc(C(F)(F)F)cc(C(F)(F)F)c1)C(/C=C/C(=O)NC1CCCCNC1=O)Cc1ccc(Cl)cc1</smiles>

Scheme 58<smiles>[R]c1ccc(C(CCCCN([R])[R])NC([R])[X])cc1</smiles>

Scheme 59: $\mathrm{R}=\mathrm{H}, \mathrm{CH}_{3} \mathrm{O}, \mathrm{NO}_{2}, \mathrm{R}_{2}=\mathrm{C}_{2} \mathrm{H}_{5}, \mathrm{CH}_{3} ; \mathrm{R}_{3}=\mathrm{C}_{2} \mathrm{H}_{5},\left(\mathrm{CH}_{2}\right)_{2} \mathrm{C}_{6} \mathrm{H}_{3}\left(\mathrm{OCH}_{3}\right)$, 3,4- $\mathrm{CH}_{2} \mathrm{Ph} ; \mathrm{R}_{4}=4-\mathrm{NO}_{2} \mathrm{C}_{6} \mathrm{H}_{4}$, 3- $\mathrm{NO}_{2} \mathrm{C}_{6} \mathrm{H}_{4}$, 3-Pyridyl, Ph, 4- $\mathrm{COOC}_{2} \mathrm{H}_{5} \mathrm{C}_{6} \mathrm{H}_{4}$, $4-\mathrm{SO}_{2} \mathrm{CH}_{3} \mathrm{C}_{6} \mathrm{H}_{5}, 4-\mathrm{OHC}_{6} \mathrm{H}_{4}, 4-\mathrm{NO}_{2} \mathrm{C}_{6} \mathrm{H}_{4}, \mathrm{PhC}_{6} \mathrm{H}_{4} \mathrm{CONH}_{2} ; \mathrm{X}=\mathrm{O}, \mathrm{NH}$.

\section{References}

1. Foster JE, Nicholson JM, Butcher R, Stables JP, Edaf'iogho IO, et al. (1999) Synthesis, Characterization and Anticonvulsant Activity of Enaminones Synthesis of Substituted Vinylic Benzamides as Potential Anticonvulsants. Bioorg Med Chem 7: 2415-2425.

2. Chan WN, Hadley MS, Harling JD, Herdon II (1998) Identification of a Series of 1,2,3,4-Tetrahydroisoquinolinyl-Benzamides with Potential Anticonvulsant Activity. Bioorg Med Chem Lett 8: 2903-2906.

3. Pierre SA, Menager S, Tombret F, Verite PH (1998) Chemical Oxidation of an Anticonvulsant N-(5'-Methylisoxazol-3-yl)-2,6-Dimethylbenzamide (D 2916). II Farmaco 53: 513-518.

4. Diouf O, Bourhim M, Lambert DM, Poupaert JH, Stables JP (1997) Anticonvulsant and Neurotoxicological Properties of 4-Amino-N-(2-Ethylphenyl) Benzamide, a Potent Ameltonide Analogue. Biomed. Phannacothempeut 51: 131-136.

5. Musso DL, Boswell GE, Mehta NB, Soroko FE, Burchall CJ, et al. (1996) Synthesis and Anticonvulsant Activity of Series of Benzamides. Eur J Med Chem 31: 331-334.

6. Bailleux V, Vallee L, Nuyts JP, Hamoir G, Poupaert JH, et al. (1995) Synthesis and Anticonvulsant Activity of some 4-Nitro-N-Phenylbenzamides. Eur J Med Chem. 30: 439-444.

7. Caliendo G, Santagada V, Perissuti E, Severino B, Fiorino F, et al. (2001) Synthesis of Substituted Benzamides as Anti-inflammatory Agents that Inhibit Preferentially Cyclooxygenase-1 but do not cause Gastric Damage. Eur J Med Chem 36: 517-530.

8. Pau A, Boatto G, Palomba M, Asproni B, Cerri R, et al. (1999) Synthesis of $\mathrm{N}$-[4-(Alkyl)Cyclohexyl]-Substituted Benzamides with Anti-inflammatory and Analgesic Activities. II Fannaco 54: 524-532.

9. Coats SJ, Schulz MJ, Carson JR, Codd EE (2004) Parallel Methods for the Preparation and SAR Exploration of N-Ethyl-4-[(8-Alkyl-8-Aza-Bicyclo[3,2.1]Oct-3-ylidene) Aryl-Methyl]-Benzamides, Powerful $\mu$ and Opioid Agonists. Bioorg Med Chem Lett 14: 5493-5498.

10. Carrsoii JR, Coats SJ, Codd EE, Dax SL, Lee J, et al. (2004) N, N-Dialkyl-4(8-Azabicycio [3.2.1]-Oct-3-ylidene) Phenylmethyl]-Benzamides, Potent Selective $\delta$ versus $\mu$ Opioid Agonists. Bioorg Med Chem Lett 14: 2109-2112.
11. Carnson JR, Coats SJ, Codd EE, Dax SL, Lee L, et al. (2004) N-Alkyl-4[(8 Azabicyclo[3.2.1]-Oct-3-ylidene) Phenylmethyl]-Benzamides, $\mu$ and $\delta$ Opioid Agonists. Bioorg Med Chem Lett 14: 2113-2116.

12. Sonda S, Kawahara T, Katayama K, Sato N, Asano K, et al. (2005) Synthesis, and Pharmacological Evaluation of Benzamide Derivatives as Selective 5-HT4 Receptor Agonists. Bioorg Med Chem 13: 3295-3308.

13. Sonda S, Katayama K, Kawahara T, Sato N (2004) Synthesis and Pharmacological properties of Benzamide Derivatives as Selective Serotonin 5-HT4 Receptor Agonists. Bioorg Med Chem 12: 2737-2747.

14. Becker DP, Flynn DL, Shone RL, Gullikson G (2004) Azaadamantane Benzamide 5-HT4 Agonists; Gastrointestinal Prokinetic SC-54750. Bioorg Med Chem Lett 14: 5509-5512.

15. Zhang D, Kohlman D, Krushinski J, Liang S, Ying BP, et al. (2004) Design, Synthesis, and Evaluation of Bicyclic Benzamides as Novel 5-HTIF Receptor Agonists. Bioorg Med Chem Lett 14: 6011-6016.

16. Arora J, Leau MB, Dube L, Jarvic K (2005) N-[(3S)-[-Benzylpyrrolidin-3-yl]-(2Thienyl) Benzainides: Human Dopamine D4 Ligands with High Affinity for (he 5- $\mathrm{HT}_{2 \mathrm{a}}$ Receptor. Bioorg. Med. Cham. Lett. 15: 5253-5256.

17. Harada H, Yamazaki $H$, Toyotomi $Y$, Tateishi H, Mine $Y$, et al. (2002) Nove $\mathrm{N}$ - [l-(1-Substiuted 4-Piperidinylmethyl)-4-Piperidinyl] Benzamides as Potent Colonic Prokinetic Agents. Bioorg Med Chem. Lett 12: 967-970.

18. Tazawa S, Masuda N, Koizumi T, Kitazawa M, Nakane T, et al. (2002) H. KDR5169, A New Gastrointestinal Prokinetic Agent, Enhances Gastric Contractile and Emptying Activities in Dogs and Rats. Eur J Pharmacol 434: 169-176.

19. Xu Y, Miao HQ, Pan W, Navarro EBC, Tonra JR, et al. (2006) N-(4-\{[4(1HBenzimidazol-2-yl)-Arylamino]-Methyl\}-phenyl)-Benzamide Derivatives as Small Molecule Heparanase Inhibitors. Bioorg. Med Chem Lett 16: 404-408.

20. Moins N, Papon J, Seguin H, Gardette D, Moreau MF, et al. (2001) Synthesis Characterization and Comparative Bio Distribution Study of a New Series of P-lodine-I25 Benzamides as Potential Melanoma Imaging Agents. Nuclear Medicine and Biology 28: 799-808.

21. Moreau MF, Papon J, Labarre $P$, Moins N (2005) Synthesis In vitro Binding and Bio distribution in B16 Melanoma Bearing Mice of New lodine-125 Sperimidine Benzamide Derivatives. Nuclear Medicine and Biology 32: 377-384

22. Narayana B, Raj KKV, Ashalatha BV, Kumari NS, Sarojini BK (2004) Synthesis of some New 5-(2-Suhstituted-I,3-Thiazol-5-yl)-2-Hydroxy Benzamides and their 2-Alkoxy Derivatives as Possible Antifungal Agents. Eur J Med Chem 39: 867-872.

23. Sener EA, Bingol KK, Arpacl OT, Yalcin I, Altanlar N, et al. (2002) Synthesis and Microbiological Activity of some N-(2-Hydroxy-4-Substituted Phenylbenzamides, Phenylacetamides and Furamides as the Possible Metabolites of Antimicrobial Active Benzoxazoles. II Farmaco 57: 45 1-456.

24. Raffa D, Daidone G, Plescia F, Schillaci D, Maggio B, et al. (2002) Synthesis and Antifungal Activity of New N-(I-Phenyl-4-Carbetoxypyrazol-5-yl)-, N-(Indazole-3yl)-andN-(Indazol--5-yL)-2-lodobenzamides. Farmaco 57: 183-187.

25. Sener EA, Bingol KK, Oren I, Aipaci OT, Yalcin I, et al. (2002) Synthesis and Microbiological Activity of Some N-(o-Hydroxyphenyl) Benzamides and Phenylacetamides as the Possible Metabolites of Antimicrobial Active Benzoxazoles Part II. Farmaco 55: 469-476.

26. Dableh LJ, Yashpal K, Rochford J, Henryl L (2005) Antidepressant Like Effects of Neurokinin Receptor Antagonists in the Forced Swim Test in the Rat. Eur J Pharmacol 507: 99-105.

27. Nielsen FE, Jacobsen P, Worsaae A (2004) POG 2-(4-Methoxyphenoxy) 5Nitro-N-(4-Suffanioylphenyl) Benzamide Activates Kir6.2/SUR1 $\mathrm{K}_{\text {ATP }}$ Channels. Bioorg Med Chem Lett 14: 5727-5730.

28. Sestili I, Borioni A, Mustazza C, Rodonionte A, Turchetto L, et al. (2004 New Synthetic Approach of N-(4-Amino-2-Methylquinolin-6-yl)-2-(4Ethylphenoxyniethyl)Benzamide (JTC-80) and its Analogues and their Pharmacological Evaluation as Nociceptin Receptor (NOP) Antagonists. Eur J Med Chem 39: 1047-1057

29. Asano T, Yoshikawa T, Usui T, Yamamoto H, Yamamoto $Y$, et al. (2004) Benzamides and Benzamidines as Specific Inhibitors of Epidermal Growth Factor Receptor and V-Scr Protein Tyrosine Kinases. Bioorg. Med. Chem 12: 3529-3542.

30. Vasudevan A, Verzal MK, Wodka D, Souers AJ (2005) Identification of Aminopiperidine Benzamides as Mchr1 Antagonists. Bioorg Med Chem Lett 15: $3412-3416$. 
Citation: Asif M (2016) Pharmacological Potential of Benzamide Analogues and their Uses in Medicinal Chemistry. Mod Chem appl 4: 194. doi: 10.4172/2329-6798.1000194

Page 10 of 10

31. Vasudevan A, Lamarehe MJ, Blackburn C, Che JL, Cullis CA, et al. (2005) Idcntification of Ortho-amino Benzamides and Nicotinamides and Nicotinamides as MCHR1 Antagonists. Bioorg Med Chem Lett 15: 4174-4179.

32. Wrohel J, Green D, Jetter J, Kao W, Rogers J, et al. (2002) Synthesis of (Bis) Sulfonic Acid, (Bis) Benzamides as Follicle-Stimulating Hormone (FSH) Antagonists. Bioorg Med Chem 10: 639-656.

33. Zhang MR, Haradahira T, Maeda T, Okauchi T, Kawabe K, et al. (2002) Synthesis and Pharmacological Evaluation of Two Potent Antagonists for Dopamine D4 Receptors: ["CjYm-50001 and N-[2-[4-(4-Chlorophenyl)-
Piperizine-I-yl[Ethyl-3-I "C] Methoxy benzamide. Nuclear Medicine and Biology 29: 233-241.

34. Gerspacher M, Vecehia LL, Mali R, Sprecher AV, Anderson GP, et al. (2001) Dual Neurokinin $\mathrm{NK}_{1} / \mathrm{NK}_{2}$ Antagonists; N-[(R,R)'(E)-I-Arylmethyl-3-(2-OxoAzepan 3-yl)Carbamoyl]Allyl-N-Methyl-3,5-Bis(Trifluoromethyl)Benzamides and 3-[N-Methylhydrazino]-N-[(R)-2-Oxo-Azepan-3-yl]Propionaniides. Chein Lett 11: 3081-3084.

35. Davydova NK, Sizova OS, Vinogradova SM, Lvov AL (2000) Synthesis and Ant fibrillatory Activity of Nibentan and its Analogues. Eur J Med Chem 35: 205-215. 